\title{
RELIGIOUS FREEDOM AND RULE OF LAW AS PANACEA FOR HUMAN FLOURISHING IN NIGERIA
}

\section{Ibrahim Imam ${ }^{1}$ Wahab O. Egbewole ${ }^{2}$}

\section{INTRODUCTION}

For over a decade now, Nigeria, and indeed the world, has witnessed conspicuous abuse of individual and collective rights to religious freedom. Muslims, in particular, have had to bear the brunt of this discrimination, which is not limited to worship or free expression of opinions, but even the public appearance by Muslim women in the Islamically prescribed mode of dress. ${ }^{3}$ In many places, such as Borno, Yobe and Adamawa in the North Eastern states of Nigeria, ${ }^{4}$ and especially in developed economies, the threats to religious freedom are calamitous. Nigerian Muslims and Christians confronting Boko Haram, Christians in Egypt and Syria, Baha' is in Iran, Shiite Muslims in Indonesia, and Sunni Muslims in Thailand and Burma - all face serious threats to their viability and even survival. This deepening abuse is closely associated with, and likely contributes to, instability, extremism, violence, poverty and underdevelopment. Astonishingly, however, opinion shapers and policy makers in the academy, secular media outlets, governments and human rights organisations continue to assign religious persecution a far lower priority than its sheer scale warrants. Nevertheless, the nature and manifestation of freedom of religion and human flourishing are an important focus for many academic disciplines today, ${ }^{5}$ all the more so in light of the increase in claims for the

1 Reader, Head of Department of Public Law and former Sub-Dean of the Faculty of Law, University of Ilorin, Nigeria.

2 Professor of Law, former Dean of Law, former Head of Department, Jurisprudence and International Law, and Director GNS, University of Ilorin, Nigeria.

3 In Asiyat Abdulkareem (through her father) and Trustees of MSSN v Lagos State Government (2016) 15 NWLR (pt 1535) 177, the appellant challenged the constitutionality of forbidding the wearing of hijab by female students in public schools on the ground that it violates their right to freedom of religion. This contention was upheld by the Supreme Court.

4 Onuoha F. 2012. "Boko Haram and the Evolving of Salafi Jihadist, Threat in Nigeria", in Onuoha CF (ed). Boko Haram: Nigeria's Extremist Islamic Sect. Doha: Al Jazeera Centre for Studies, 182.

5 Durham WC (Jr). 1996. "Perspectives on Religious Liberty: A Comparative Framework", in Van der Vyver JD and Witte J (Jr) (eds). Religious Human Rights in Global Perspective: Legal Perspectives. Leiden: Martinus Nijhoff; Obioha PU. 2009. “Ethics, Religion and Humanity: Rethinking Religion in 21st Century Africa", Global Journal of Humanities 8(1-2):27-34; Obilor JI. 2002. "Religion as the Bedrock of Any Democracy: A Key to Nigerian Survival", Journal of Nigerian Languages and Culture 3:63; Odumuyiwa EA. 2006. "Religion and child development", Journal of Religion and Human Values 4\&5:1-15; Okafor FU. 2007. 
recognition and implementation of religious ideas, identities, values, practices and institutions in governance, in a way that has prompted a departure from previous perceptions about religion. ${ }^{6}$

A key event giving insight into the status in Nigeria of violation of human rights, rule of law and infringement of human flourishing is a recent and brazen act of intimidation, persecution and killing of innocent Muslims as they were exercising their fundamental right to freedom of religion, which was accompanied by untamed acts of lawlessness by the military. The juxtaposition of these events happened on 20 December 2015. The followers of Ibrahim Yaqoub El-Zakzaky, spiritual leader of Islamic Movement of Nigeria, had a clash with the military in the city of Zaria during $\mathrm{Al}$ Quds Day procession, consequent upon which many of his unarmed followers were killed, including three of his children. The leader and his wife were brutally dealt with, seriously injured, arrested and have been held in custody without any charge or trial to date. ${ }^{7}$ Yet, notwithstanding the fact that they were granted bail by competent courts in recognition of their fundamental right, the several calls by human rights organisations and a series of protests demanding for their release by the government continue to fall on deaf ears. ${ }^{8}$

This chapter also draws an insight from the disharmonious relationship between Salafism (Ahlus Sunnah) and Sufism, movements of Islamic faith with different interpretations of Islam and historically diverse reflects some of the changes and violent conflicts in Nigeria today. Salafism is associated with literalist, strict and puritanical approaches to Islam. Sufism is associated with the rectification of the soul (tasawuf) and is mainly focused in becoming a better Muslim and person to achieve a higher status in paradise. While there are Nigerian Muslims who believe that Salafism and Sufism "have common characteristics", the Salafi response to Sufism has been called "polemical". ${ }^{9}$ Accordingly, Nigerian Muslim Salafists have been remorselessly hostile to devotional Sufi practices, arguing that Sufism is incompatible with true Islam practice, and one of the elements debasing modern-day Islam. Relations between the two movements have consistently been ones in which

"New strategies for curbing Ethnic and religious Conflicts in Nigeria", in Harura D (ed). Ethnicity in Nigerian Politics. Enugu: Fourth-Dimension, 98-135.

6 See the essays in Bidegain AM and Sanchez Soler JJ (eds). 2010. "Religion in Latin America", Hemisphere (special issue) 19(1).

7 Shadjareh M and Choudhury A. 2014. Nigeria Reports: Kaduna Massacres and the Role of the Military. Great Britain: Islamic Human Rights Commission. The Islamic Movement enjoys the support of between 10-15 million people across Nigeria.

8 Kaduna State High Court ordered that El-Zakzaky be released from Department of State Services (similar to the US FBI) detention into police custody within 45 days. El-Zakzaky and his wife were to be paid the sum of fifty million naira in compensation. The judge announced that the justification of "holding him for his own protection" was not sufficient. See "Court orders DSS to release Shiite leader, pay him N50M compensation", Pulse, 2 December 2016.

9 Baker AH. 2011. Extremists in Our Midst: Confronting Terror. London: Palgrave Macmillan, 2; See also Geaves R. 2006. "Learning the Lessons from the Neo-Revivalist and Wahhabi Movements", in Malik J and Hinnells J (eds). Sufism in the West. London: Routledge, 142-159. 
the "battle line is drawn" in practically every Muslim country, but particularly in Nigeria. This type of relationship is antithetical to human flourishing and contrary to the right to freedom of religion necessary for attainment of a flourishing society. ${ }^{10}$

A similar phenomenon undermining human flourishing in Nigeria, but which is also global in impact and nature, has to do with the differences between Salafist and Shiites Muslims. Although both are Islamic movements that profess similar faith, their differences stem from conflicting religious ideology and beliefs that have led to political conflicts. For example, while the Sunnis believe that the prophet Muhammad had no rightful heirs and that leaders should be elected through votes amongst Islamic community, the Shiites believe that only Allah (SWT) can select leaders and therefore all successors must be direct descendants of Prophet Muhammad. Another contentious issue concerns the Mahdi (Guardian). While Salafists hold that Mahdi is not yet been born and anticipate his arrival, Shiites believe that Mahdi was born in 869 and will return to Earth under Allah's order. There is also a difference which concerns prayer. Muslims generally pray five times daily, but Shiites have the option of combining the prayer times Dhuhr with Ashr and Magrih with Ishai. ${ }^{11}$ The question is: How do we achieve a flourishing society in face of inter- or intra-religious conflict arising from ideological differences, particularly when fundamental rights of citizens are not respected and protected and rule of law deliberately disobeyed?

The chapter primarily frames and conceptualises human flourishing within the context of religion freedom and rule of law. The chapter articulates the effects of religion in attempt to elucidate, amongst other things, the expected appropriate relation between one person to another, in order to determine what counts as well-being of the individual with his fellow human beings. Religious orthodoxy is a useful paradigmatic tool that determines for us the right way to live, so that we can attain human flourishing, and it shows that true flourishing depends on the flourishing of the whole society, where freedom of religion is respected and rule of law is achieved. Indeed, human beings, irrespective of their backgrounds, are entitled to experience this freedom as equal citizens under the rule of law, while government is also duty bound to ensure that the freedom is not used to harm fellow citizens. Government has the duty to bring religious beliefs respectfully to the discussion of society's governance and global affairs. Put differently, sustainable religious freedom is the legally protected and culturally accepted right to choose, change, share or reject beliefs of any kind, including religious ones, and to bring those beliefs to public discussions. Against this background, it is contended in this chapter that key global opinion shapers and policy makers, as well as the general public, ought to back serious measures to promote religious freedom and explore its magnitude and implications more systematically, but only if they

10 Knysh A. 2007. "Contextualising the Salafi-Sufi Conflict", Middle Eastern Studies 43:507.

11 Triana M. 2017. Managing Diversity in Organization: A Global Perspectives. London: Routledge, 159; Newman AJ. 2013. "Introduction", in Twelver Shiism: Unity and Diversity in the Life of Islam, 632-1722. Edinburgh: Edinburgh University Press, 2. 
believe that it will help their societies flourish. It is not sufficient to demonstrate that religious persecution, whether against Muslims or Christians, is prevalent and on the increase, which presently appears to be the focus of most advocacy efforts on religious freedom, but its utility in promoting harmonious and flourishing society.

This chapter is divided into four main parts. The first part dwells on conceptual exposition of rule of law, human flourishing and freedom of religion, focusing on their role in the continuum of well-being, peace and development of a flourishing society. The second part addresses the links between religious freedom and rule of law and their concomitant interaction. The third part discusses the significance of rule of law with a view to showing how freedom of religion is can be guaranteed and protected in order to equip people to live a flourishing life in Nigeria. Finally, in its concluding sections, the chapter discusses the bigger picture of freedom of religion and rule of law, along with the complex and interesting account of how government and individual actions can lead society towards flourishing.

\section{CONCEPTUAL ISSUES}

\section{Concept of rule of law}

This part of the chapter is not concerned with different legal theorists' approaches towards the concept of rule of law; instead, the concept of "rule of law" is discussed as the basis of modern democratic society. For successful performance of any policy, it is imperative that there is enforcement of law. ${ }^{12}$ This is because laws are enacted for the well-being of the people to maintain peaceful coexistence amongst the conflicting forces in society, particularly in societies like Nigeria, which is very heterogeneous. In other words, a prime object of making laws is to maintain law and order in society and develop a peaceful environment for the progress of the inhabitants of a sovereign state. Consequently, the concept of rule of law plays a vital role in this process. ${ }^{13}$ The doctrine of rule of law lays down that the law is supreme; hence, the government must act according to law and within the limits of the law. It is the legal principle that law should govern a nation, as opposed to the nation being governed by arbitrary decisions of individual or particular government officials. ${ }^{14}$ It primarily refers to the influence and authority of law within society, as constraints upon behaviour, including behaviour of government officials. ${ }^{15}$

Historically, the term "rule of law" has its foundation in the French phrase "le principe de légalité", meaning "the principle of legality", which refers to government

12 Cole JY. 1997. The Library of Congress: The Art and Architecture of the Thomas Jefferson Building. WW Norton \& Company, 113; Garner BA (ed). Black's Law Dictionary. Ninth Edition. Eagan, MN: Thomson Reuters, 1448.

13 Chesterman S. 2008 "Rule of Law", American Journal of Comparative Law 59:346.

14 Chesterman, "Rule of Law".

15 Clarke D. 1998. "The Many Meanings of the Rule of Law", in Kanishka J (ed). Law, Capitalism and Power in Asia. New York: Routledge. 
established on philosophy of law and not the whims of human beings. ${ }^{16}$ In a wider perspective, "rule of law" means that law is supreme and is above every individual. No individual, whether affluent or underprivileged, a political leader or the governed, of a particular faith or ethic or any other criterion, is above law; thus, they should obey the law. Accordingly, rule of law presupposes that government authority can only be exercised within the laws adopted through an established procedure. The principle is intended to safeguard against arbitrary rulings in individual cases. ${ }^{17}$

The principle of rule of law is intended to be a safeguard against arbitrary or despotic actions of the government authorities. The rule of law has been described as a "rare and protean principle of our political tradition". ${ }^{18}$ The rule of law centrally comprises "values of regularity and restraint, embodied in the slogan of 'a government of laws, not of men'"'. ${ }^{19}$ In the modern context, rule of law is fairly wide and therefore sets up an ideal for any government to achieve. Rule of law implies that the functions of the government in a free society should be so exercised as to create conditions in which the dignity of human as individual is upheld. This dignity requires not only the recognition of civil or political rights, but also the creation of economic, social and cultural conditions which are essential to the full development of his human personality. ${ }^{20}$

In a proper sense, rule of law implies a democratic system, a constitutional government where criticism of the government is not only permissible, but also a positive good, and where parties based on competing politics or interests are not only allowed, but also encouraged. Where this exists, the other consequences of rule of law must follow. ${ }^{21}$ The term "rule of law" does not specify anything about the manner in which laws are to be made or anything specific in the way of fundamental rights and objectives or directive principles. In a higher sense, it provides for two significant concepts: (1) that law must be obeyed by the people and (2) that law must be made in such a way that it is able to direct the activities of its subjects. ${ }^{22}$

16 Cooper JM and Hutchinson DS (eds). 1997. Complete Works by Plato. Indianapolis, IN: Hackett Publishing, 1402.

17 Bingham T. 2010. The Rule of Law. London: Penguin, 3; Black A. A World History of Ancient Political Thought Oxford: Oxford University Press.

18 Haruna BA. 2012. "Analysis of the Rule of Law: Meaning, Content and Scope", in Madaki AM (ed). Challenges of Constitutional Governance in Nigeria: Legal Essays in Honour of Dr. Samson Sani Ameh. Kaduna: Meadal Micro Computers Limited, 406-407.

19 Bingham, The Rule of Law.

20 This concept was developed by the International Commission of Jurists, known as Delhi Declaration, 1959, which was confirmed in Lagos in 1961.

21 Levinson B. 2006. "The First Constitution: Rethinking the Origins of Rule of Law and Separation of Powers in Light of Deuteronomy", Cardozo Law Review 27(6):1853-1888.

22 Craig PP. 1997. "Formal and Substantive Conceptions of the Rule of Law: An Analytical Framework", Journal of Public Law 2:476. 
The common ingredients of rule of law are:

(1) A government bound by and ruled by law;

(2) Equality before the law;

(3) The establishment of law and order;

(4) The efficient and predictable application of justice; and

(5) The protection of human rights. ${ }^{23}$

It may therefore be correctly asserted that rule of law does not denote and cannot represent any government under any law. Rather, it means rule by a democratic law, a law which is passed by a democratically elected legislative assembly, after thorough and adequate debate and discussion, fairly and equitably applied. An individual who actively exercises his freedom of religion within the limits of the law and reason properly achieves human flourishing. In the same model, as social beings, an individual's capacity to reason essentially can only be developed in society where rule of law is respected.

\section{Concept of human flourishing}

Human flourishing is not limited to pleasure, virtue or affluence, but incorporates other aspects of the concept of human rights that facilitate complete manifestation and full exercise of the potentialities that characterise us as human beings. ${ }^{24}$ This is because the contemporary revival in the studies of human flourishing is accompanied by studies on the rhetoric of happiness, which transcends social, political and economic development of individual. In a liberal articulation, goodness or badness, rightness or wrongness, appropriateness or inappropriateness of one's actions is a component of flourishing, if and only if it is constitutive of flourishing. ${ }^{25}$ Something is therefore a means of flourishing if and only if it tends to enhance the components of flourishing on balance, meaning the flourishing of all aspects of life, including family, social, political, ethical, economical, emotional, intellectual and spiritual. ${ }^{26}$ These categories of what one might broadly call contributors to flourishing are not mutually exclusive. A component of flourishing may also be a means to other components. ${ }^{27}$

23 Stephenson M. 2008. "Rule of Law as a Goal of Development Policy”, World Bank Research, January; Harrison J. 1997. "Substantive Due Process and the Constitutional Text", Virginia Law Review 88:493.

24 Achrill JK. 1980. "Aristotle Eudaimonia", in Rorty AO (ed). Essays on Aristotle's Ethics. London: University of California Press, 19.

25 Harman G. 1983. "Human Flourishing, Ethics and Liberty", Philosophy \& Public Affairs 12(4):307-322.

26 See Nussbaum MC. 2002. "Aristotle in Human Nature and Foundations of Ethics", in Altham JEJ and Harrison R (eds). World, Mind, Ethics: Essays on Ethical Philosophy of Bernard William. New York: Cambridge Press, 209-215.

Harman, "Human Flourishing, Ethics and Liberty". 
What, then, constitutes human flourishing? A comprehensively good or worthwhile life for human persons is a question that still elicits an overwhelming diversity of responses. One obvious reason for this is that human flourishing has diverse substantive conceptions, which differ in what they single out as components of human flourishing and in how they are to be weighted and related. ${ }^{28}$ Consequently, it is apposite to always distinguish between personal value, a life being good for the person living it, and ethical value, a life being worthy or ethically good in the broadest sense. Indeed, this is the basis for the argument in this chapter that the differences between Salafis and Shiites, as well as the Boko Haram insurgency, which has not spared Muslims despite the fact that they profess the same faith, is a departure from the sacrosanct tenets of Islamic ethical values essential for a flourishing ummah (society). The values of these insurgents are surely not features of human lives, such as brotherhood, friendship, knowledge, art or love that can contribute to both personal and ethical value. ${ }^{29}$

It manifests when the two measures of personal value and ethical value are weighted differently and diverge strongly in regard to other features of human flouishing. Thus, personal value is related to a person's experiences, to their being, for instance, enjoyable, intense, interesting, rich and diverse. But personal value would also seem to be related to a person's success in the world. These two ideas easily come apart. People may not know their successes and failures, and their inner lives may be dulled by successes and much enriched by failures even when they do. ${ }^{30}$

The notion of ethical value also suggests two main ideas. It is associated with the idea of good character, of a person having admirable aims and ambitions, virtuous maxims and dispositions, noble feelings and emotions. But it is also associated with ethical achievement and with the ethical significance of the person's conduct. ${ }^{31}$ These two ideas also come apart easily, since how one's character manifests itself in the world, including the practice of religion, is significantly affected by one's social starting position and talents, as well as by circumstances and luck. Some achievements may well result from base motives, such as motive of religious intolerance. $^{32}$

Distinguishing these four dimensions - experience, success, character and achievement - may give some structure to the concept of human flourishing. Within this structure, one can then ask further whether these dimensions are exhaustive in their contribution to human flourishing. ${ }^{33}$ What more specific components of flourishing should be distinguished within each of them, different ways in which

28 Sumner LW. 1987. The Moral Foundations of Rights. Oxford: Oxford University Press.

29 Sumner, The Moral Foundations of Rights.

30 Rawls J. 1971. A Theory of Justice. Cambridge, MA: Harvard/Belknap, 242-269.

31 Rawls, A Theory of Justice.

32 Rawls, A Theory of Justice, 253.

33 Sumner, The Moral Foundations of Rights. 
experiences may be good and undertakings successful, different character traits and kinds of achievements? The complexities indicated by these questions are one major reason for the diversity of views about what constitutes human flourishing.

Another important reason for the multiplicity of perspectives on religion and human flourishing is that this notion appears to us in various ways. In the case of freedom of religion, for example, it makes a difference whether one poses the question of flourishing from within, in regard to one's own life (i.e. freedom to practise one's religion), or from without (i.e. protection against undue interference), or in reference to the lives of others (i.e. respect for other person's right to his/her faith). ${ }^{34}$ And it matters also whether the question is posed prospectively, with practical intent and in search of normative guidance for how to use one's power to shape one's own life and the lives of others, or retrospectively, in the spirit of mere evaluation. ${ }^{35}$

The relevance of these distinctions can be appreciated by noting that the choice of perspective has a substantial bearing on our perception of the relative importance of the dimensions of human flourishing distinguished above. ${ }^{36}$ It seems common, for example, for individuals to give more weight to ethical value than personal value when reflecting prospectively on their own religious practice in life than when reflecting prospectively on the religious practice of others even within the same religion. ${ }^{37}$ For example, there are different groups with different ideologies in both the Islamic and Christian faiths, all of which profess the same God, but to ensure religious freedom and human flourishing, each must weigh their ethical values of faith against individual or group ideological belief. The Quran affords recognition not only to gender equality, but to individual autonomy. Through individual autonomy, it is possible to advance the ethics of the Quran, and with these Islam's social and compassionate responsibility for a flourishing society. Again, the point is that it seems appealing to give more weight and think about another's life perspectively and prospectively. But in order to reach any such adequate conception, it must be accepted that human flourishing appears differently to us depending on the perspective we take and the prospective goals to which we aspire.

The idea of human flourishing is central not only to our personal and ethical reflections about our own lives and the lives of those around us, but also to our social, economic and political discourse about our social institutions and policies. Here it is, in particular, our idea of justice that affords yet another perspective on the question of human flourishing. In its ordinary meaning, the word "justice" is associated with the morally appropriate and, in particular, equitable treatment of

Tamanaha BZ. 2004. On the Rule of Law: History, Politics, Theory. Cambridge: Cambridge University Press. Contemporary Moral Philosophy. Cambridge: Cambridge University Press. 
persons and groups. ${ }^{38}$ Currently its most prominent use is in the moral assessment of social institutions, understood as a social system's practices or "rules of the game", which govern interactions amongst individual and collective agents as well as their access to material resources. Such social institutions define and regulate property, division of labour, sexual and kinship relations, as well as political and economic competition. They also govern how collective projects are adopted and executed, how conflicts are settled, and how social institutions themselves are created, revised, interpreted, and enforced. ${ }^{39}$

The totality of the more fundamental and pervasive institutions of a social system has been called its institutional order or basic structure. Prominent within our political discourse is, then, the goal of formulating and justifying a criterion of justice by which to assess the degree to which the institutions of a social system are treating the persons and groups they affect in a morally appropriate and, in particular, an even-handed way. ${ }^{40}$ Such a criterion of justice presupposes a measure of human flourishing, one specially designed for the task of evaluating how social institutions treat the persons they affect. ${ }^{41}$

\section{Concept of freedom of religion}

Religion is sacred in nature and character, thus, the proper exercise of freedom of religion or human flourishing, can only be attained in the right kind of society, a society that encourages virtuous religious life. The religious virtues are just those capacities that enable us to reason properly or to live well in accordance with the dictates of our faith. This can only be realised if individual practice of religion is situated in a network of appropriate relationships with other religions. It may be right to posit, therefore, that it is in recognition of the significance of freedom of religion to human flourishing, that the Constitution of the Federal Republic of Nigeria, 1999, guarantees the right to freedom of religion as a fundamental right. Specifically, Section 38 provides:

(1) Every person shall be entitled to freedom of thought, conscience, and religion, including freedom to change his religion or belief, and freedom (either alone or in community with others, and in public or in private) to manifest and propagate his religion or belief in worship, teaching, practice and observance.

(2) No person attending any place of education shall be required to receive religious instruction or to take part in or attend any religious ceremony or observance if such instruction, ceremony or observance relates to a religion other than his own, or a religion not approved by his parent or guardian. 
(3) No religious community or denomination shall be prevented from providing religious instruction for pupils of that community or denomination in any place of education maintained wholly by that community or denomination.

(4) Nothing in this section shall entitle any person to form, take part in the activity or be a member of a secret society.

Additionally, there are a number of secondary rights which complement the protection and enjoyment of religious freedom in Nigeria. Such rights include freedom of association, including the right to belong to any denomination within a religion, ${ }^{42}$ the right to private and family life, ${ }^{43}$ the right to freedom of expression to propagate religion without any hindrance ${ }^{44}$ and the right to freedom of movement. ${ }^{45}$

A careful perusal of the language of the above section demonstrates the fact that religion is an attribute of a flourishing society for an individual person, ${ }^{46}$ as well as the generality of citizens. ${ }^{47}$ It is important in a country like Nigeria, with many religious faiths (Islam, Christianity and African traditional religions) to foster peaceful coexistence and well-being of citizens, so that rights are guaranteed for "every person". Significantly, the fundamental right to freedom of religion granted every person in Nigeria is not just because they are Nigerian citizens, but because they are all human beings. In this sense, religion, being so closely connected to human dignity in many religions, is also an attribute of a human flourishing and essential for peace, security and stability of the country. Hence, on this premise, the role of the rule of law implies that the right to freedom of thought, conscience or religion must not be prevented without lawful justification. The limits to religious freedom, too, are not in dispute, especially where it impinges on or threatens the rights of others or where it puts the welfare of society or public health in jeopardy or threaten peace and security. Otherwise, ensuring liberty of conscience and freedom of religion is an important component of human flourishing.

\section{HUMAN FLOURISHING AND RELIGIOUS FREEDOM}

Even as a human right and guarantor of human flourishing, religion is a major source of contention in Nigeria. In part, this is because of the inevitable tension between the freedom to practise one's religion and the freedom of others to practise their religion and to enjoy other freedoms. But in another part, it is because the liberal bias of the human rights movement has resulted in the human rights movement incorporating

42 Constitution of the Federal Republic of Nigeria, sec 40.

43 Constitution of the Federal Republic of Nigeria, sec 37.

44 Constitution of the Federal Republic of Nigeria, sec 39.

45 Constitution of the Federal Republic of Nigeria, sec 41.

46 The Oxford Advanced Learners' Dictionary defines "person" as "a human as an individual".

47 The Oxford Advanced Learners' Dictionary defines "citizen" as "a person who has the legal right to belong to a particular country". 
the conflicts and tensions over religion within liberalism. ${ }^{48}$ The recent CAN reaction to the Sukuk ${ }^{49}$ alternate funding policy as a government attempt to Islamise Nigeria, along with objections to several other Islamic development proposals embraced by the government, such as membership in the Organisation of Islamic Countries (OIC), calls into question the type of relationship that exists amongst the Nigeria's multiple religions and has implications for human flourishing. ${ }^{50}$ In a very real sense, a political and legal structure that protects individual rights must be seen as a necessary prerequisite for the possibility that human flourishing can occur in a social setting without favouring the flourishing of one individual over another. In such a system of guaranteed rights, the possibility exists that people might flourish in diverse ways in a variety of communities and cultures without requiring that the possible flourishing of any other person be diminished.

The potentially negative implications of religious and ideological dichotomy on human flourishing can be demonstrably underscored in the devastating effect of Boko Haram ("western education is forbidden") insurgency in Nigeria. Available statistics shows that over the last dozen years, from 1 June 2006 to 31 May 2018, the Boko Haram conflict has caused a total of 32,842 fatalities, almost one third of the 101,480 deaths recorded during this period in the Nigeria Watch database. ${ }^{51}$ Roughly, the same numbers of people were killed directly by the insurgents $(16,666)$ and indirectly by security forces $(16,182)$. At first glance, Boko Haram members seemed to be more focused on attacking civilians than the army.

48 See, generally, D’Soza R. 2008. "Liberal Theory, Human Rights and Water Justice: Back to Square One", Law Social Justice and Global Development (1); and Moravcsik A. 1995. "Explaining International Human Rights Regimes: Liberal Theory and Western Europe", Journal of International Relations 1(2):157-189.

49 According to Financial Times Lexicon, Sukuk (i.e. legal instruments, deeds or cheques) are Islamic bonds, structured in such a way as to generate returns to investors without infringing Islamic law that prohibit riba, or interest. Sukuk securities are securities of equal denomination representing individual ownership interest in a portfolio of eligible existing or future assets. Sukuk was the form of alternative funding that the Federal Government of Nigeria considered for the purpose of raising as much as five million dollars from the foreign debt market. See Adam NJ and Thomas A. 2004. "Islamic Fixed-income securities: sukuk", in Jaffar S (ed). Islamic Asset Management: Forming the Future for Shari'a-Compliant Investment Strategies. London: Euromoney Books, 73; Thomas A. 2003. "What are Sukuk?" American Journal of Islamic Finance (AJIF.org LLC) cited in Saeed A and Salah O. 2014. "Development of Sukuk: Pragmatic and Idealist Approaches to Sukuk Structures", Journal of International Banking Law and Regulation 1:45-46.

50 Ele CO. 2018. "Islamization of Nigeria: Implication for Sustainable Peace", International Journal of Social Sciences and English Literature 2(1):1. Evidence of Christian intolerance can be seen in this author's misconceived belief that Islam has multi-dimensional approaches to ensuring that Nigeria becomes an Islamic state and this means that peace is compromised variously in the enterprise of Islamisation.

51 Nigeria Stability and Reconciliation Program (NSRP). 2016. Nigeria Watch Project: Sixth Report on Violence (2016), 12. Nigeria Watch monitors violence in Nigeria in order to provide statistics, analyse trends and draw maps that can help to locate dangerous and secure people. 
Out of 16,666 fatalities, 1,073 could not be identified as civilians or combatants, and 1,689 were military, police, spies, prison wardens, or militiamen of the Civilian Joint Task Force (CJTF). Most of the victims $(13,904)$ were civilians, including 25 foreigners and 582 women and children. During the same period, the security forces killed "only" 1,309 civilians, including 96 women and 31 children, while 1,445 casualties could not be identified. Most of their victims $(13,428)$ were considered to be "terrorists". 52

The gravitational influence of Boko Haram's disposition to criminality pursuant to their personal conception of religion can be seen in the way in which their thinking and acting is based in their own spatiotemporal locality. This is simply because a group, whether Boko Haram or the wider society, cannot think or act unless they choose to think or act in a coordinated manner with one another. Incidentally, the right to think, hold or express opinion guaranteed under Section 40 of the Nigerian Constitution does not extend to undermining the rights of others in society. In this framework, individual perceptions of religious freedom ought to be pursued in association and affiliated with others. This preposition is grounded on the fact that human beings have the ability to cooperate and achieve objectives and human flourishing through voluntary action. Thus, to properly construct a paradigm for human flourishing in Nigeria as a free society, it is necessary to go back to the absolute fundamentals of human nature. There is need to have a precise understanding of the nature of the human person and human differences. It is not in doubt that human beings are a distinct species in a natural world, with lives that are governed by means of each person's free will and individual conceptual consciousness. However, from a constitutional rights perspective, it is incumbent on adherents of faith to respect the rights of others.

An understanding of human rights and human flourishing can similarly be fathomed from the fact that, in most parts of the world, attempts to question certain religious tenets have in most situations led to wanton killing and destruction of property, with many people displaced. ${ }^{53}$ This is evident from the observations of political scientist Okwudiba Nnoli, ${ }^{54}$ who, in explaining the reason why religious violence occurs in diverse societies, states:

Religious differences have a high potential for separating people from one another. Throughout history these differences have been the basis of tension, animosity and even war. Many times a certain fanaticism is associated with people of a different religion, or hampers mutual trust and confidence when such relations happen to exist. This is because

52 NSRP, Nigeria Watch Project: Sixth Report on Violence (2016).

53 The activities of Boko Haram have led to the death of no less than 100,000 and displaced over 2.6 million people, most of whom are living in IDP camps in various parts of the country and neigbhouring countries of Niger and Cameroon. See Onuoha FC and Oyewole S. 2018. Report: Anatomy of a Violent Group in Nigeria. Doha: Al Jazeera Centre for Studies.

54 See, generally, Nnoli O. 1978. Ethnic Politics in Nigeria. Enugu: Fourth Dimension Publishers Limited. 
religion tends to define what constitutes appropriate social behaviour. When this definition is at cross purposes with another, normal relations become difficult. ${ }^{55}$

Ideally, the role of religion in negotiating human flourishing should be central to peaceful coexistence driven by tolerance. However, the clash of civilisations has been considered by some to be decisive in determining the nature of the flourishing. Religion, which ought to unite people of the same faith and guide their relationship with others of different faiths, across the world, ${ }^{56}$ regrettably tends to pit members of different faiths into almost constant ideological confrontation and often into violent conflictual relationship. This is apart from the impact of the existing internal differences in each religion, which manifests dramatically based on doctrinal differences, such as the doctrinal differences evident between Salafi and Shiite Muslims against the Tijjaniyah and Qodiriyyah followers, ${ }^{57}$ and between Catholic and Protestant Christians and the prosperity churches. On the contrary, however, freedom of religion in Islam is sacrosanct as a necessity for a flourishing society.

Islam recognises and ensures right to freedom of consciousness and conviction to all human beings. Muslims can invite non-Muslims to Islam, but they cannot compel them to embrace Islam or force their faith on them, and neither can any Muslim impose his perception of religion on another Muslim. The Quran says:

There is no compulsion in religion. Verily, the Right Path has become distinct from the wrong path. Whoever disbelieves in Tâgh ût and believes in Allâh, then he has grasped the most trustworthy handhold that will never break. And Allâh is All-Hearer, All-Knower [Al-Quran in Al-Baqara:256]. And again Quran says: Say [O Muhammad to these Mushrikûn and Kâfirûn]: $\mathrm{O}$ Al-Kâfirûn disbelievers in Allâh, in His Oneness, to you be your religion, and to me my religion [Islamic Monotheism; Al-Qur'an in Al-Kâfirûn:109]. ${ }^{58}$

It is, thus, posited that interreligious dialogue, ${ }^{59}$ which is significant to guarantee unity amongst the diverse faiths in Nigeria and to secure violence-free relationships, has not been maximally taken advantage of because of intolerance and unnecessary rivalry amongst the different religions in the country.

55 Nnoli, Ethnic Politics in Nigeria.

Ibrahim J. 1991. "Religion and Political Turbulence in Nigeria", Journal of Modern African Studies 29(1):115-136.

57 The Ahlis Sunnah "people committed to the propagation of the prophet's teachings" do aggressively condemn the followers of Ahl Tijjaniyah and Qodiriyyah (named after their founders and who are Sufist) on the grounds that they introduce into religious activities innovations (Bidiah), which are not acceptable in Islam. Notwithstanding, all the groups still uphold the main foundation of Islamic Faith, that is, the divinity of Allah as the only God and Mohammed His messenger.

58 Ali AY. 1978. The Holy Quran. Text, Translation and Commentary. New Revised Edition. Beltsville, MD: Amana Corporation.

59 An example is the Centre for Islamic Civilization and Inter Faith Dialogue at Bayero University, Kano, Nigeria. 
Due to this shortcoming, interreligious dialogue cannot be effectively claim to have contributed to human flourishing in Nigeria. Evidence abounds that religious zealots and bigots have taken advantage of the country's religious complexity, competitive division, intolerance and frivolous rivalry to exploit unsuspecting followers for their selfish interests, be it for economic or political benefit. ${ }^{60}$ Indisputably, this demonstrates that incitement of religious violence does not occur in a vacuum, but rather is reinforced by other inherent conditions that necessitate its occurrence, and these conditions can be internal, external or both, depending on the manifest reality. Internally, religious violence occurs when particular adherents perceive their belief system to be superior to other religions, when a sense of religious deprivation is nurtured or when a competitive equality with other religion is established..$^{61}$ Competitive equality is the commonest and most recurrent source of disputes amongst Islamic movements. ${ }^{62}$ Their leaders often noticeably make "superiority claims" on the basis of ideology, popularity, knowledge, establishment date or leadership, which are then taken to great length.

It is, thus, incontrovertible that human flourishing can be compromised, simply because religion itself can be manipulated, especially when adherents of religion feel emotionally attached more to it than to the respective utility of religious activities. This explains the fact that religious manipulation and agitation are not just a function of poverty, corruption and democratic deficits, to reference the explanation proffered to account for the rise of Boko Haram sect. To certain extent, it is well-known that Boko Haram leaders manipulate their followers by combining Salafiyah religious interpretations with ideologies of victimhood, which Muslims perceive around the world. Similarly, apart from empirical support of political influence, there is also a distinct narrative about the relationship between Islam and Western culture, as well as emulations of Islamic State rhetoric to justify holding of territory in Northern Nigeria. ${ }^{63}$ We cannot but agree with the view of the noted sociologist Emile Durkheim, who maintained, "Men feel overpowered by a force greater than themselves, which results from the collective effervesce of the occasion. The individual is conveyed into a world which appear to him to be utterly different to that of the everyday utilitarian activity to which the bulk of his life is devoted." 64

Unlike other beings, a person's survival and flourishing depends on cognition at a conceptual level. This is why, irrespective of Nigerian diversities in culture, ethnic,

60 Haynes J. 2009. “Conflict, Conflict Resolution and Peace Building: The Role of Religion in Mozambique, Nigeria and Cambodia", Commonwealth and Comparative Politics 44(1): 152-175.

61 Onapajo H. 2012. "Politics for God: Religion, Politics and Conflict in Democratic Nigeria", The Journal of Pan African Studies 4(9):42-66.

62 This is attitudinal or an inclination of a person or group to regard themselves as slightly better than the other or of superior status.

63 See Schurman-Kauflin D. 2008. Disturbed: Terrorist Behavioral Profiles. Sun City, AZ: Violent Crimes Institute, 8.

64 Culled from Giddens A. 1971. An Analysis of the Writings of Marx, Durkheim and Max Weber. Cambridge: Cambridge University Press, 10. 
language and religion, it must be understood that we are all of one species with a definite nature and who are uniquely configured through individuating features that should ordinarily unit us. This is supported by the provision of the Quran, which says: "O mankind! Fear your Guardian Lord, who created you from a single person, created out of it, His mate, and from them twain scattered (like seeds) countless men and women; fear Allah through whom you demand your mutual rights and be heedful of the wombs (that bore you) for Allah ever watches over you." 65 Though individuality is vital to human nature, humans are still responsible for achieving and sustaining their lives within the confines of the law and tolerating one another without allowing their own choices and actions to undermine the rights of others.

Human activities are self-conscious driven, purposefully pursued and deliberately chosen. This proposition applies equally to the actions of Boko Haram. Firstly, in a way similar to other human organisations, Boko Haram articulates a central philosophy as guiding principle. Secondly, they establish alliances with rival factions of the Boko Haram movement and within the broader and external jihadi groups as a strategy for sustainability, much in the way that organisations build partnerships and networks. Thirdly, they delegate core responsibilities to other commanders, who operate on the group's behalf while their leader remains anonymous, a division of roles as commonly found in most other organisations. ${ }^{66} \mathrm{It}$ can therefore be asserted that Boko Haram insurgents are pursuing their activities deliberately, based on their self-consciousness and their understanding, or perhaps their misunderstanding, of their religion. ${ }^{67}$ Their actions are determined by their ideological indoctrination without due regard to the rights of other religious faiths, leading to events that have caused disruption of human flourishing.

It is arguable that under the right to freedom of religion guaranteed by the Nigerian Constitution, members of Boko Haram are entitled to make choices and initiate action based what they believe, even though such freedom does not extend to actions which involve purposeful, intentional and normative behaviour that endangers human freedom and flourishing. It is a matter of record that since the start of Boko Haram insurgency in the North Eastern Nigeria, numerous individuals have been rendered refugees and scores of innocent citizens denied their right to life. It is hereby contended that human flourishing, through mental action or thinking, which constitute the ultimate free actions and individuals, ought to be directed and focused on the willingness to preserve and protect the rights of others in terms of religious conception. From an Islamic perspective, the distinguishing of a good person is that they take pleasure in moral action. Thus, Islamic ethics,

65 Quran, An-Nisa, 4 v 1.

66 Abdulbasit K. 2015. "Defining and Understanding the Religious Philosophy of JihadiSalafism and the Ideology of Boko Haram", Politics, Religion and Ideology 16(2-3):173-200.

Shaaba MM. 2017. "Absolutism in Religion and Global Peace: Boko-Haram Factor in Nigeria and Its Educational Imperatives", World Journal of Education 7(2):11-18; Brakoniecka S. 2015. "The Beginnings of the Boko Haram Rebellion from a Micro-level Perspective", Hemispheres: Studies on Cultures and Societies 30(2):89. 
or Ilm al-Akhlaq, deals with the ways to maintain virtues at their optimum level, to avoid wrongdoing and to do what is right and desirable. The scope of Islamic ethics is far-reaching and comprehensive, because it deals with relationship between humans and God, amongst human personas and communities, between humans and other creatures of the universe and within the innermost selves of human beings, all of which are significant for human flourishing. ${ }^{68}$ This demonstrates the positive connection of religiosity and freedom of religion with human flourishing.

Human flourishing occurs when people do what they ought to do and want to do. The goal of a person's life is to live rationally and to develop both the intellectual and moral virtues. ${ }^{69}$ Nonetheless, as asserted by Nigerian religion scholar Sunday Awoniyi, instead of advancing a flourishing society by means of religion or as springboard for the inculcation and improvement of social ethical values, which are fundamental to achieving correct human behaviour as it relates to productivity and nation-building, Nigerian leaders are using religion as an instrument to play a divide-and-rule game. ${ }^{70}$ The politicisation and exploitation of religion for egocentric purposes by some individuals has presented obstacles to human flourishing in Nigeria and has often generated disagreement and tension amongst people of different religious faiths, especially between adherents of Christianity and Islam. ${ }^{71}$ Notwithstanding, there are attributes central to human nature in the practice of religion, the development of which leads to human flourishing and a good human life. Underscoring the significance of the linkage between human rights and human flourishing is the ability of individuals to enjoy the protection of their rights in a way that leads to flourishing. It follows that human flourishing is always particularised as regards to its inextricable connection with human freedom in society, where rule of law is sacrosanct and observed. In terms of freedom of religion, human flourishing occurs when people are practising their faith through free choice.

68 Syeda SS and Ali AZ. 2015. "Religious Faith, Flourishing and Self-Efficacy in Young Adults", Global Journal of Arts, Humanities and Social Sciences 3(10):34-45.

69 See the following relevant African Literature: Bewaji John AI. 2004. "Ethics and Morality in Yoruba Culture", in Wiredu K (ed). A Companion to African Philosophy. Oxford: Blackwell Publishing; Oluwole SB. 1984. "The Rational Basis of Yoruba Ethical Thinking", The Nigerian Journal of Philosophy 4(1\&2):14-25; Idowu BE. 1962. Olodumare: God in Yoruba Belief. London: Longmans Group Ltd. Other relevant literature include: Kudadjie JN. 1973. “Does Religion Determine Morality in African Societies? A Viewpoint", Ghana Bulletin of Theology 3(5):30-49; Danquah JB. 1994. The Akan Doctrine of God: A Fragment of Gold Coast Ethics and Religion. London: Butterworth Press; Ebijuwa T. 1996. "Conscience, Morality and Social Responsibility in an African Culture", Quest: Philosophical Discussions 9(2):95-100; Gyekye K. 1995. An Essay on African Philosophical Thought: The Akan Conceptual Scheme. Revised Edition. Philadelphia: Temple University Press (original edition published by Cambridge: Cambridge University Press, 1987).

70 Awoniyi S. 2015. "Religious Ethics and Development: The Nigerian Experience", Studies in Sociology of Science 6(3):1-7.

71 Asogwa NU. 2011. "Religion and Religious Pluralism in a Nation Building, the Nigerian Experience", Nsukka Journal of Religion and Cultural Studies 4(1):144-148; Nkechinyere O. 2011. "Religion and Challenge of Sustainable Democracy in Nigeria", Nsukka Journal of Religion and Cultural Studies 4(1):86-103. 
In the case of Nigeria, with its multi-religious status, a prudent action according to one individual may not be a prudent action in the view of another, even within the same religion. For instance, amongst Nigerian followers of Islamic faith, there are movements and groups with different philosophies and understandings of religion, and this has occasioned conflict, especially when one group is determined to foist its philosophy on others. This is contrary to Islamic ethics, as shown in the passage of the Quran which says: "And hold fast all together, by the Rope which Allah (stretches out for you) and be not divided among yourself; and remember Allah's favour on you for you are enemies and He joined your hearts in love so that by His Grace, you became brother and you were on the brink of the pit of fire and he saved you from it. Thus Allah makes His signs clear to you so that you may be guided."72

Ideally, the needless conflicts resulting from people's different religious ideological dispositions would not have attained a place in our society if, adherents of religious faiths had respected rule of law as well as each and every persons' fundamental right to freedom of religion guaranteed in the Constitution. Paradoxically, however, religious bigots, such as the Boko Haram terrorists, have employed legitimisation of violence in the name of God in Nigeria. Whereas the right of every citizen to practise, to profess, to express and to enjoy their religion is taken as sacrosanct, it is only possible to accomplish this through social coordination to assure human flourishing in society.

Religious freedom is attainable when individuals prudently choose and undertake religious practice without any hindrances and demonstrate respect for others with different faiths. Religious freedom is a requisite for human flourishing, which requires a harmonious relationship, as well as tolerance of other people who profess faiths distinct from one's own. In this connection, rule of law, liberty and freedom are significant to entrenching social and political conditions necessary for the possibility of human flourishing. Invariably, religious freedom and rule of law can be interpreted as a natural and ultimate end of human flourishing. Employing freedom of religion to achieve human flourishing within the precinct of personal flourishing would involve individual's rational use of religious virtues in the pursuit of freely and rationally chosen faith. Therefore, individual enjoyment of religious freedom, as envisaged in the Nigerian Constitution, is considered to be proper if it leads to the flourishing of the person in relationship with others. Human flourishing thereby becomes a moral accomplishment and a fulfilment of human capacities in society.

It is, thus, contended that what is lacking in the practice of religion in Nigeria and what undermines human flourishing can be explained in terms of the inability or deliberate refusal of religious adherents, particularly Muslims and Christians, to use practical reasoning to consider which concrete instantiations of human values and virtues will comprise human flourishing and well-being, based on the unique needs, circumstances, and capacities of various individuals and communities. In order to achieve this, followers of religious faiths must appreciate certain characteristics of 
human flourishing, which encompass a wide variety of constitutive ends, such as tolerance, harmonious relationship, knowledge, the development of character traits, religious pursuits, love, charitable activities, allegiance to other persons and causes, self-efficacy, material well-being and pleasurable sensations. In reality, to flourish, a person must pursue religious goals that are rational to them, both as an individual and as a human being.

\section{RULE OF LAW AND HUMAN FLOURISHING}

One of the most profound enigmas in human flourishing discourse lies in the area of compliance with rule of law and what the government power should constitute in the realm of ensuring the practice of religion within the law. What constitutes government capacity in human flourishing has become well known as the defining element of the autonomy required to implement and sustain individual fundamental rights without any discrimination. That is, the state must have the competence to insulate itself from particular interests, especially in a multi-religious society like Nigeria. ${ }^{73}$ Where people with diverse ethno-religious, cultural and linguistic backgrounds come together, such as in Nigeria, there ought to be the potential for peaceful coexistence, without prejudice to the inevitability of occasional conflict. The conduct of political affairs should demand tolerance, which may not exist in some cases. Invariably, exercising tolerance is an acknowledgment of differences and disagreement, a paradigm and decision to coexist despite these differences, and to allow them to regulate rather than destroy individual conduct. The above postulation is fundamental to both the rule of law and human flourishing, which are about equality and the right of people to manifest their religion without any hindrance. In the event that consensus may be a desired end, if only to resolve conflict, tolerance is the tool that helps us flourish and manage the dynamics of any pluralistic religious society. Instructively, the value of tolerance goes beyond that, because in protecting and cultivating diversity, tolerance also creates the conditions for human flourishing. Even so, disagreement and dissent can be seen as processes of "mutual incitement" in a positive sense. When people disagree, they are in fact inciting each other to think anew and differently about established ideas or beliefs. It is through disagreement that we dislodge ourselves from rigid ways of thinking and being and refine our ideas and positions.

In a civilised society, balancing the phenomenon of freedom of religion and human flourishing requires rule of law in every facet of governance. It is important that the government view of the observance of rule of law is not only one of propaganda, but actually exists and is realised in reality. This means the constitutionality of protecting individual freedom of religion for achieving human flourishing, demands that governance must be readily pursued with mutual respect. Where people with diverse ethno-religious, cultural and linguistic background come together as nation, as in Nigeria, there ought to be potential peaceful coexistence, notwithstanding

73 Constitution of the Federal Republic of Nigeria, sec 10, provides: “The government of the Federation or of a State shall not adopt any religion as a State Religion." 
the inevitability of conflict. The conduct of affairs demands tolerance, which may or may not exist. Consistent with the demand, exercising tolerance would mean an acknowledgment of differences and disagreements, and a decision to coexist despite. By implication, the differences, rather than destroy them ought to regulate individual conducts.

Rule of law is integral to and necessary for religious freedom. ${ }^{74}$ Attempts to protect the right of individuals to practise their religion of choice without a functional legal system may result in social disorder, as in the case of Shiite followers protesting the detention without trial of their leader El-Zakzaky. ${ }^{75}$ Rule of law facilitates geopolitical stability and global peace. It offers the possibility of holding accountable those who commit acts of aggression and violate humanitarian laws of war, and it is central to the establishment of a rights-respecting, post-conflict regime. The incessant crisis of the Boko Haram insurgency has forced the Nigerian government to focus attention on its skewed perception of rule of law, as a means to make insurgents accountable and to legitimise their arrest, prosecution and punishment. Consequent upon this, the Nigerian government promulgated Anti-Terrorist Act of 2016. The fight against the Boko Haram insurgency has been characterised as a war on the nation's way of life in terms of democracy, human rights and rule of law.

It is undisputable fact that the Boko Haram terrorist attacks on the people in North Eastern part of Nigeria struck at everything the country stands for - its unity in diversity, peace, freedom, tolerance and human rights. It affects the very idea of a united human family, despite all the Nigerian government's striving to create an egalitarian society, based on the rule of law. Conversely, rule of law plays a crucial role in ensuring that civil liberties, particularly freedom of religion, are not encroached upon in the eagerness to round up suspected terrorists. This is why government itself needs to follow due process in dealing with issues of religion, because it is on record that the extrajudicial killing of Yusuf Muhammed, the leader of Boko Haram, by the police was the foundation and real reason for the escalation of their activities in the first instance. The insurgency sought to jeopardise not just Nigerian peace and security but the movement towards socio-economic development and political stability. The Nigerian government's approach to the issue calls for serious caution. El-Zakzaky is still being detained without prosecution or restoration of his freedom after he was admitted to bail. The government attitude herein cannot but be described as a deliberate disrespect for rule of law. ${ }^{76}$

74 Stephenson, "Rule of Law as a Goal of Development Policy".

75 As late as 28 October 2018, the followers of Sheikh Ibrahim El-Zakzaky were still protesting the detention without trial of their leader. Ogundipe S. 2018. "Many Killed as Nigerian Soldiers Fire Shiite Protesters in Abuja", Premium Times, 28 October; See also Omonobi K and Erunke J. 2018. "Death, Blood as Shiites, Soldiers Clash in Abuja" Vanguard, 28 October; Islamic Human Rights Commission. 2009. "Press Release - Nigeria - Breaking News Police fire on peaceful protest in Zaria", IHRC.org.uk, 18 September.

76 There was a clash between Shiite Islamic Movement, protesting the continuing detention of their leaders, and the combined force of the military and the police; scores of the protesters have been killed by soldiers. 
The resultant effect has been consistent violent protests by his followers, many of whom were killed by the security. How can a country flourish when government who should respect rule of laws are violators of rule of law?

\section{CONCLUSION}

In conclusion, the significant issues to be considered for human flourishing in Nigeria should include how to distinguish between abnormal and normal religious practices, as reflected in constitutional prohibition and restriction on membership of an unlawful association. Key questions are: (1) how to define and control religious extremism and fanaticism without unduly restricting freedom of religious belief and practice, (2) how to ensure free speech while restricting hate speech in dissemination of religion and (3) how to prevent the abuse of defamation suits against those who allegedly engage in religious stereotyping or who incite religious hatred by spreading malicious untruths about a particular religious group, while still allowing legitimate suits to be brought. Religious education is another contested area, with many countries divided on whether religious education should be allowed at all and whether the government should fund religious schools.

Acknowledging the impossibility of offering a justification of rights persuasive to all, some rights proponents have sought comfort in a pragmatic consensus on human rights issues or held out hope for the emergence of an overlapping consensus. But the pragmatic or overlapping consensus quickly breaks down once one moves beyond feel-good discussions about the desirability of the broad wish list of abstract rights contained in human rights documents to the difficult issues of the justifications for such rights and how they are to be interpreted and implemented in practice.

Many human rights issues implicate deep moral commitments, including religious views, traditional gender roles, different notions of freedom and autonomy and fundamental beliefs about the relationship of the individual to the state and other members of society. Because human rights issues raise these deep commitments and because the international human rights movement's pretence of universalism, there may be overlapping consensus to particular outcomes that may be defensible on liberal principles. However, this consensus may also be at odds with the principles and commitments of other traditions and the interconnectedness of religious freedom and human flourishing should be reasonably clear from the foregoing. In sum, in as much as human flourishing refers to the various ways in which humans can, over the course of their lives, develop and live well, a guarantee of freedom of religion can be an effective mechanism to drive it. Such flourishing is likely to be achieved only if certain religious norms are adopted and observed. Thus, in recognition of our sociality, freedom of religion for human flourishing will be self-legislating, since it is in virtue of our capacity to determine the conditions of our sociality that our dignity consists. 
The authors wish to emphasise here that interconnectedness between freedom of religion and human flourishing being proposed is not one of consistent necessity or adequacy, simply because a person whose religion is respected by other members of the society may not necessarily flourish. This is due to the fact that such a person may be short of certain fundamental bases (i.e. socially and economically) for flourishing. Be that as it may, religious freedom provides an important assurance and platform for securing a flourishing society. Conversely, guaranteeing freedom of religion is not absolutely enough for human flourishing, especially in the absence of rule of law. 